\title{
Role of combined hystero-laparoscopy in the evaluation of female infertility as one step procedure: a retrospective analytical study of 250 patients
}

\section{B. Ramesh, Shraddha Neminath Kurkuri*}

\author{
Department of Gynaecological Endoscopy \& Infertility, Dr. Ramesh Hospital, Bangalore, Karnataka, India
}

Received: 02 December 2015

Accepted: 08 January 2016

\section{*Correspondence:}

Dr. Shraddha Neminath Kurkuri,

E-mail: snk3061988@gmail.com

Copyright: (c) the author(s), publisher and licensee Medip Academy. This is an open-access article distributed under the terms of the Creative Commons Attribution Non-Commercial License, which permits unrestricted non-commercial use, distribution, and reproduction in any medium, provided the original work is properly cited.

\begin{abstract}
Background: Infertility is defined as a failure of a couple to conceive after having regular, unprotected sexual intercourse for one year. To determine the role of combined hystero-laparoscopy in the evaluation of female infertility patients with no significant clinical/ ultrasonography findings and to calculate the incidence of various pathological conditions in the female reproductive tract leading to infertility.

Methods: This retrospective analytical study was done in 250 patients with primary and secondary infertility. It was conducted at our hospital from December 2014 to November 2015. We assessed the role of combined hysterolaparoscopy female infertility patients with no significant clinical/ ultrasonography findings and calculated the incidence of various pathological conditions in the female reproductive tract leading to infertility.

Results: Out of 250 patients, 165 had primary and 85 had secondary infertility. The patients in secondary infertility group were older compared to primary group. The most common intrauterine pathology in both the groups was uterine septum. Next most common intrauterine lesion was endometrial polyp. Adnexal adhesions and endometriosis were the most common abnormalities detected in laparoscopy in both groups. The prevalence of unilateral and bilateral tubal block was almost equal in both groups. The operative interventions, both hysteroscopic and laparoscopic were also noted.

Conclusions: Combined hystero-laparoscopy is a safe, effective and reliable method in comprehensive evaluation of female infertility. It is a very useful tool in detecting the correctable missed pelvic abnormalities in patients with the normal ovulation and semen analysis. It will also help us to take decision regarding the need for ART in required patients, thus avoiding further emotional and financial trauma to the couples.
\end{abstract}

Keywords: Infertility, Hysteroscopy, Laparoscopy

\section{INTRODUCTION}

Infertility is defined as a failure of a couple to conceive after having regular, unprotected sexual intercourse for one year. It affects about $10-15 \%$ of the couples. ${ }^{1,2}$ The ability to observe and treat pathology during laparoscopy has made it a gold standard to evaluate pelvic pathology. ${ }^{3}$ Similarly, visualizing uterine cavity and identifying the possible pathology has made hysteroscopy an essential part of infertility evaluation. The abnormalities of pelvic structures can be resolved in hystero-laparoscopy at the same time. ${ }^{4}$ Thus, it becomes prognostic and therapeutic procedure rather than only diagnostic.

Hence the need for study in order to assess the role of combined hystero-laparoscopy in female infertility and also to formulate the appropriate plan of management. 
The main objectives were (1) to determine the role of combined hystero-laparoscopy in evaluation of female infertility patients with no significant clinical or ultrasonography findings and (2) to calculate the incidence of various pathological conditions in the female reproductive tract leading to infertility.

\section{METHODS}

This retrospective analytical study was done in 250 patients with primary and secondary infertility. It was conducted at our hospital from December 2014 to November 2015. We assessed the role of combined hystero-laparoscopy in female infertility patients with no significant clinical/ ultrasonography findings and calculated the incidence of various pathological conditions in the female reproductive tract leading to infertility.

\section{Inclusion criteria}

Patients between 20 - 40 years of age with primary or secondary infertility were included in the study. Primary infertility patients were those who had never conceived before, while secondary infertility patients had conceived before at least once irrespective of the outcome.

\section{Exclusion criteria}

Patients with anovulation and abnormal husband semen analysis were excluded from the study. Also patients with active genital infections or any contraindications to the operation (severe cardiac/ respiratory disorder, acute generalized peritonitis, anaesthetic problems, uncontrolled diabetes mellitus, severe anemia, and severe urinary tract infection) and patients not willing for surgery were excluded.

\section{Patient recruitment}

After taking informed written consent, detailed history of the patient, general physical and gynaecological examination was done and they were recorded in a proforma. Other tests such as husband semen analysis, hormonal assay and pelvic ultrasonography were carried out. The study group was selected with regards to appropriate inclusion and exclusion criteria. Hysterolaparoscopy was carried out in the early follicular phase of the menstrual cycle on in-patient basis under general anaesthesia, as a one-step procedure.

Karl Storz hysteroscope (4 $\mathrm{mm}$ diameter) was used for diagnostic hysteroscopy. Hysteroscope was introduced and the cervical canal, uterine cavity, endometrium and both Ostia were thoroughly inspected. Therapeutic interventions in the form of septal resection, polypectomy, myomectomy, tubal cannulation, removal of calcified endometrium and synechiolysis (adhesiolysis) were done wherever required by operative scope (2.9 mm diameter).
Karl Storz laparoscope (5 $\mathrm{mm}$ diameter) was introduced after creating pneumoperitoneum intraumbilically and thorough inspection of uterus, anterior and posterior culde-sacs, fallopian tubes, ovaries and rest of the pelvic peritoneum, appendix and liver surface was performed. Any abnormality seen was noted, including adhesions. Chromopertubation was done in all of our cases using dilute methylene blue dye. Therapeutic interventions were performed at the same sitting like adhesiolysis, operative procedure for endometriosis, myomectomy, cystectomy, cyst aspiration, adenomyomectomy, salpingectomy, fimbrioplasty, fimbrial cystectomy, and surgeries for uterine anomalies wherever required.

Any relevant positive findings in hystero-laparoscopy were noted and incidence of different lesions was calculated. Therapeutic interventions were also noted and tabulated. Appropriate statistical measurements like mean, rates, ratios, percentages, proportions, $\mathrm{p}$-value and number were used.

\section{RESULTS}

Out of 250 patients, $165(66 \%)$ women had primary infertility and the 85 (34\%) had secondary infertility (Table 1, Figure 1). Abnormal hystero-laparoscopic findings were seen in $75.6 \%$ of primary infertility group (125 out of 165 patients) and $76.5 \%$ of secondary infertility (65 out of 85 patients). The patients in secondary infertility group $(31 \pm 4.8$ years $)$ were comparatively older compared to primary group (26 \pm 3.5$)$ (p-value $<0.05$ )

Table 1: Prevalence of normal and abnormal hysterolaparoscopy in infertility.

\begin{tabular}{|lllll|}
\hline $\begin{array}{l}\text { Proced } \\
\text { ure }\end{array}$ & \multicolumn{2}{c|}{ Primary infertility } & \multicolumn{2}{l|}{ Secondary infertility } \\
\hline & $\begin{array}{l}\text { Normal } \\
(\%)\end{array}$ & $\begin{array}{l}\text { Abnorma } \\
1(\%)\end{array}$ & $\begin{array}{l}\text { Normal } \\
(\%)\end{array}$ & $\begin{array}{l}\text { Abnorma } \\
1(\%)\end{array}$ \\
\hline $\begin{array}{l}\text { Hystero } \\
\text { laparos } \\
\text { copy }\end{array}$ & $\begin{array}{l}40 \\
(24.2)\end{array}$ & $\begin{array}{l}125 \\
(75.6)\end{array}$ & $\begin{array}{l}20 \\
(23.5)\end{array}$ & $\begin{array}{l}65 \\
(76.5)\end{array}$ \\
\hline
\end{tabular}

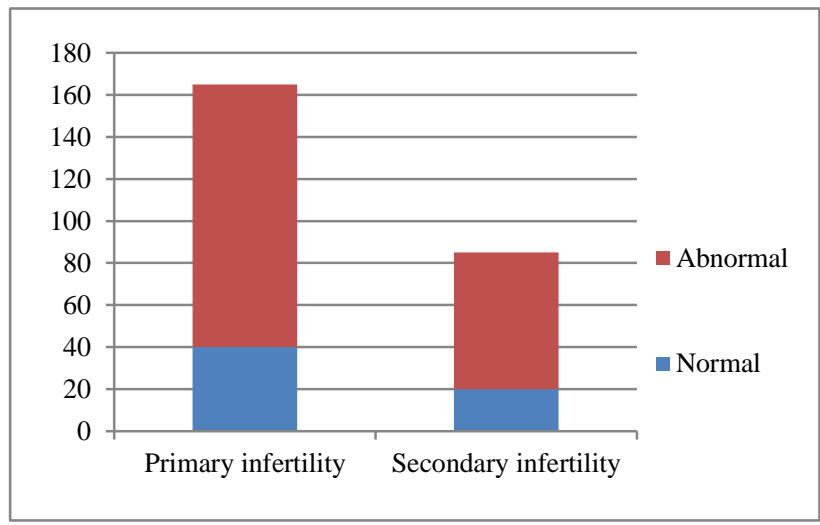

Figure 1: Prevalence of normal and abnormal hystero-laparoscopy in fertility. 
The most common intrauterine pathology in both the groups was uterine septum accounting for about $13.7 \%$ (26 out of 190 patients) (Table 2, Figure 2). The septate uterus had large fibrous midline septum in its cavity. Out of 26 patients having septate uterus, only 6 had complete septum. Next most common intrauterine lesions were endometrial polyp and myoma accounting for about $12.6 \%$ (24 out of 190 patients).

Table 2: Incidence of abnormal hysteroscopic findings in infertile patients.

\begin{tabular}{|c|c|c|c|}
\hline Findings & $\begin{array}{l}\text { Primary } \\
\text { infertility } \\
(\%)\end{array}$ & $\begin{array}{l}\text { Secondary } \\
\text { infertility } \\
(\%)\end{array}$ & $\begin{array}{l}\text { Total } \\
(\%)\end{array}$ \\
\hline Septum & $\begin{array}{l}17 \\
(13.6)\end{array}$ & $\begin{array}{l}09 \\
(13.8)\end{array}$ & $\begin{array}{l}26 \\
(13.7)\end{array}$ \\
\hline Myoma / Polyp & $\begin{array}{l}16 \\
(12.8)\end{array}$ & $\begin{array}{l}08 \\
(12.3)\end{array}$ & $\begin{array}{l}24 \\
(12.6)\end{array}$ \\
\hline $\begin{array}{l}\text { Ostia } \\
\text { blocked/fibrosed }\end{array}$ & $\begin{array}{l}08 \\
(6.4)\end{array}$ & $\begin{array}{l}03 \\
(4.6)\end{array}$ & $\begin{array}{l}11 \\
(5.8)\end{array}$ \\
\hline $\begin{array}{l}\text { Endometrium } \\
\text { (inflamed/calcifie } \\
\text { d/irregular) }\end{array}$ & $\begin{array}{l}08 \\
(6.4)\end{array}$ & $\begin{array}{l}02 \\
(3.1)\end{array}$ & $\begin{array}{l}10 \\
(5.3)\end{array}$ \\
\hline $\begin{array}{l}\text { Hypoplastic } \\
\text { uterus }\end{array}$ & $\begin{array}{l}03 \\
(2.4)\end{array}$ & $\begin{array}{l}01 \\
(1.5)\end{array}$ & $\begin{array}{l}04 \\
(2.1)\end{array}$ \\
\hline $\begin{array}{l}\text { Adhesions } \\
\text { (intrauterine } \\
\text { synechia) }\end{array}$ & 00 & $\begin{array}{l}02 \\
(3.1)\end{array}$ & $\begin{array}{l}02 \\
(1.1)\end{array}$ \\
\hline
\end{tabular}

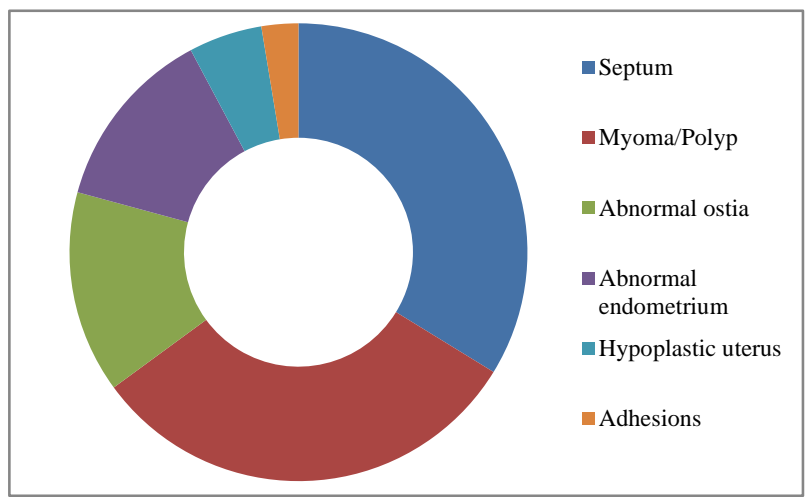

Figure 2: Incidence of abnormal hysteroscopic findings in infertile patients.

Adnexal adhesions and endometriosis (41.6\%) 79 out of 190 patients) were the most common abnormalities detected in laparoscopy in primary and secondary infertility groups (Table 3, Figure 3). The prevalence of unilateral and bilateral tubal block was almost equal in both the groups (Table 4, Figure 4).

The various operative interventions, both hysteroscopic and laparoscopic were noted and tabulated as mentioned in (Table, Figure 5) and (Table, Figure 6) respectively. There was no major surgical or anesthetic complication in any of our operated patients except minimal abdominal pain and minimal per vaginal bleeding in some.
Polycystic ovaries (excluded from the study) were seen in 40 patients and we did bilateral ovarian drilling in these patients.

Table 3: Incidence of abnormal laparoscopic findings in infertile patients.

\begin{tabular}{|llll|}
\hline Findings & $\begin{array}{l}\text { Primary } \\
\text { infertility } \\
(\%)\end{array}$ & $\begin{array}{l}\text { Secondary } \\
\text { infertility } \\
(\%)\end{array}$ & $\begin{array}{l}\text { Total } \\
(\%)\end{array}$ \\
\hline $\begin{array}{l}\text { Adnexal } \\
\text { adhesions }\end{array}$ & $28(22.4)$ & $12(18.5)$ & $40(21.1)$ \\
\hline Endometriosis & $28(22.4)$ & $11(16.9)$ & $39(20.5)$ \\
\hline Myoma & $25(20)$ & $10(15.4)$ & $35(18.4)$ \\
\hline Adenomyosis & $07(5.6)$ & $03(4.6)$ & $10(5.3)$ \\
\hline $\begin{array}{l}\text { Ovarian } \\
\text { pathology }\end{array}$ & $18(14.4)$ & $07(10.8)$ & $25(13.2)$ \\
\hline $\begin{array}{l}\text { Tubal } \\
\text { pathology }\end{array}$ & $13(10.4)$ & $07(10.8)$ & $20(10.5)$ \\
\hline $\begin{array}{l}\text { Uterine } \\
\text { anomaly }\end{array}$ & $03(2.4)$ & 00 & $03(1.6)$ \\
\hline $\begin{array}{l}\text { Fimbrial } \\
\text { agglutination }\end{array}$ & $04(3.2)$ & 00 & $04(2.1)$ \\
\hline Fimbrial cyst & $03(2.4)$ & 00 & $03(1.6)$ \\
\hline
\end{tabular}

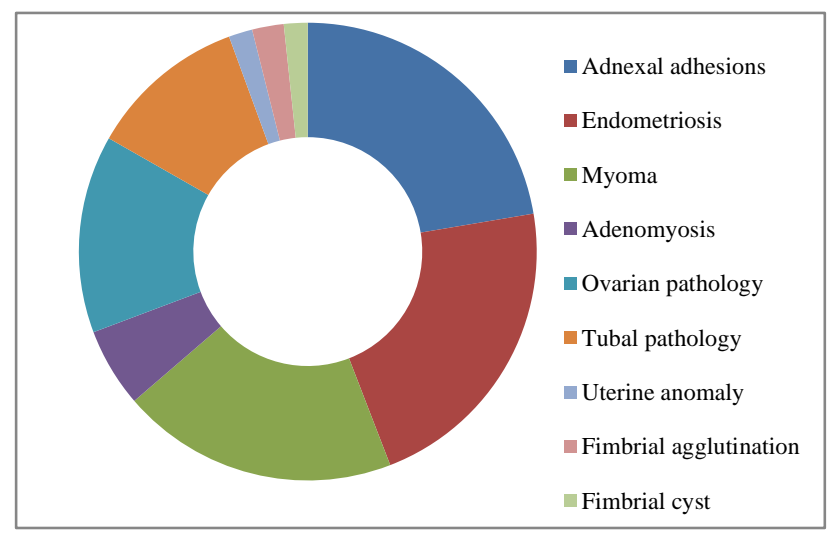

Figure 3: Incidence of abnormal laparoscopic findings in infertile patients.

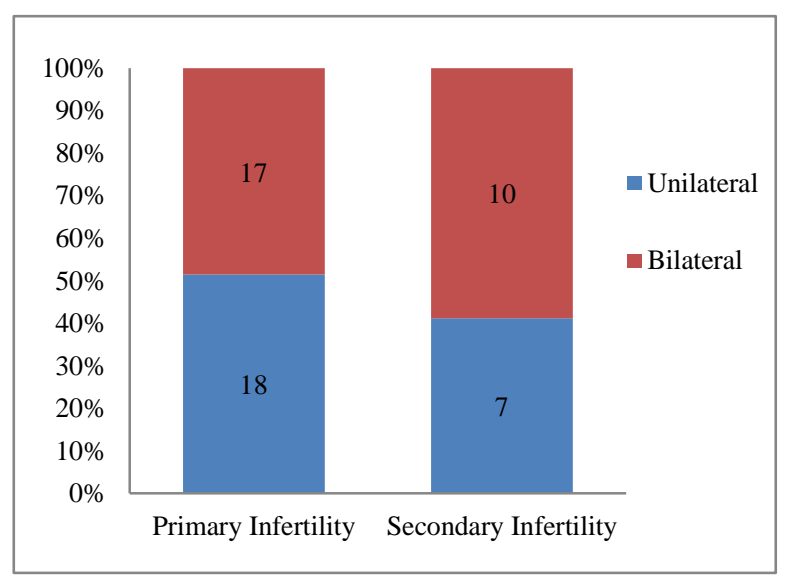

Figure 4: Prevalence of complete tubal block (CPT) in infertile patients. 
Table 4: Prevalence of complete tubal block (Chromopertubation test: CPT) in infertile patients.

\begin{tabular}{|lll|}
\hline Findings & $\begin{array}{l}\text { Primary } \\
\text { infertility }(\%)\end{array}$ & $\begin{array}{l}\text { Secondary } \\
\text { infertility }(\%)\end{array}$ \\
\hline Unilateral & $18(14.4)$ & $08(12.3)$ \\
\hline Bilateral & $17(13.6)$ & $09(13.9)$ \\
\hline Total $(\%)$ & $35(28)$ & $17(26.2)$ \\
\hline
\end{tabular}

Table 5: Hysteroscopic interventions in infertile patients.

\begin{tabular}{|lll|}
\hline Interventions & Number & Percentage \\
\hline Myomectomy/Polypectomy & 24 & 12.6 \\
\hline Adhesiolysis & 02 & 1.1 \\
\hline Tubal cannulation & 08 & 4.2 \\
\hline Septal resection & 26 & 13.7 \\
\hline $\begin{array}{l}\text { Removal of abnormal } \\
\text { endometrial tissue }\end{array}$ & 10 & 5.3 \\
\hline
\end{tabular}

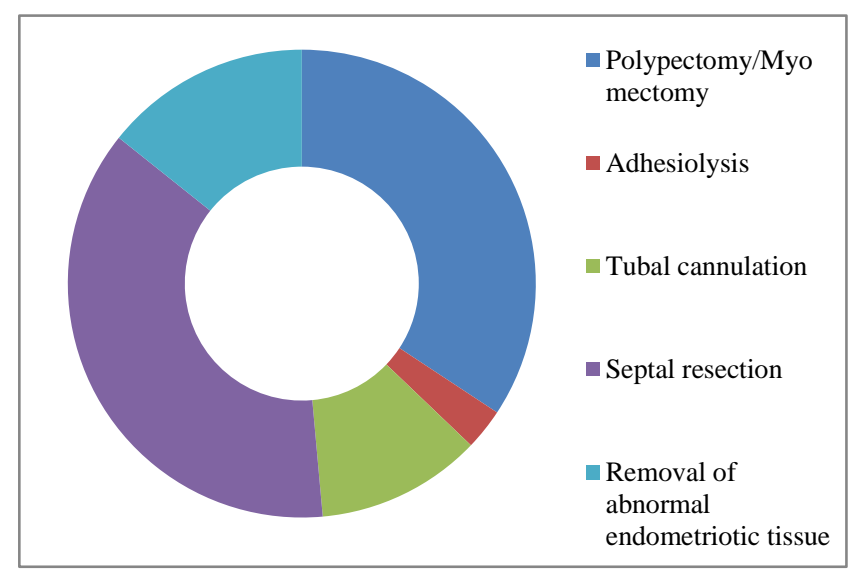

Figure 5: Hysteroscopic interventions in infertile patients.

Table 6: Laparoscopic interventions in infertile patients.

\begin{tabular}{|lll|}
\hline Interventions & Number & Percentage \\
\hline Myomectomy & 35 & 18.4 \\
\hline $\begin{array}{l}\text { Operative procedure for } \\
\text { endometriosis }\end{array}$ & 39 & 20.5 \\
\hline Adhesiolysis & 40 & 21.1 \\
\hline Adenomyomectomy & 10 & 5.3 \\
\hline Ovarian cystectomy & 18 & 9.5 \\
\hline Ovarian cyst aspiration & 07 & 3.7 \\
\hline Salphingectomy & 12 & 6.3 \\
\hline Fimrioplasty & 04 & 2.1 \\
\hline Fimbrial cystectomy & 03 & 1.6 \\
\hline $\begin{array}{l}\text { Resection of non- } \\
\text { communicating uterine horn }\end{array}$ & 02 & 1.1 \\
\hline $\begin{array}{l}\text { Unification of bicornuate } \\
\text { uterus }\end{array}$ & 01 & 0.53 \\
\hline
\end{tabular}

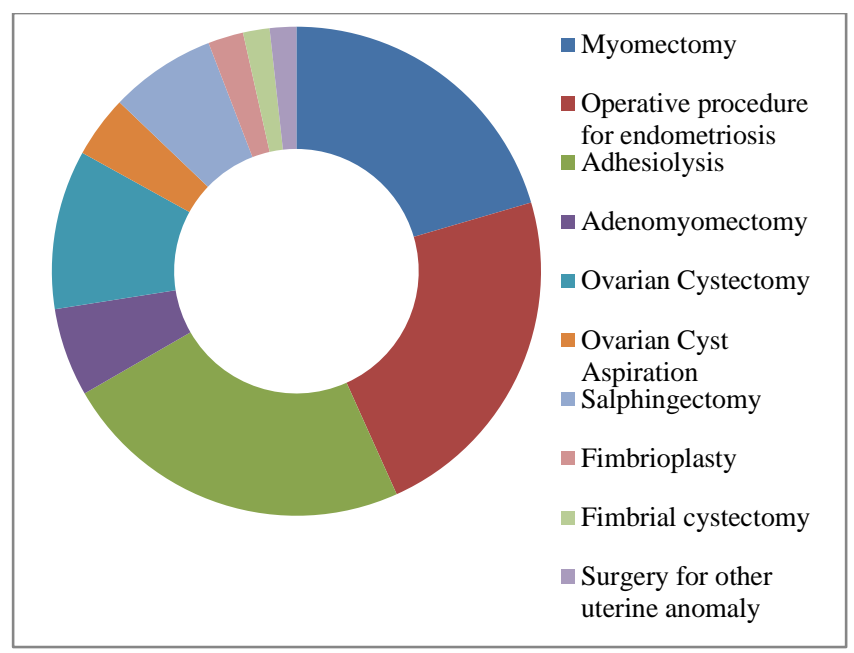

Figure 6: Laparoscopic interventions in infertile patients.

\section{DISCUSSION}

Infertile women with normal ovulation, normal pelvic ultrasound finding, normal hormonal profile and normal husband semen analysis have higher possibility of having tubo-peritoneal and subtle endometrial pathologies. The subtle changes are better picked up on magnification with hystero-laparoscopy. These women have a lot of emotional and financial trauma on undergoing series of procedures like HSG (hysterosalpingography), laparoscopy and hysteroscopy over a period of time, before being referred for ART (Assisted Reproductive Technique). Performing hysterolaparoscopy as 'one step procedure' in these women will be more beneficial.

Tubo-peritoneal pathology is responsible for infertility in $40-50 \%$ of the cases, while uterine pathology accounts for $15-20 \%$ of cases. Other factors include ovulatory dysfunction (30-40\%) and male factor (30-40\%). ${ }^{1,2}$ Our hospital being a referral and a tertiary centre, abnormal hystero-laparoscopic findings were high accounting for $75.6 \%$ in primary infertility group and $76.5 \%$ in secondary infertility.

Hysteroscopic abnormalities are common in infertile patients; intrauterine abnormalities have been detected in $19-62 \%$ of infertile women in some studies. ${ }^{5}$ Hysteroscopy is a safe and reliable diagnostic as well as therapeutic procedure with complication rate of $2.35 \%{ }^{6}$ Monitored by laparoscopy, the complication rate of hysteroscopy declined significantly. Hysterolaparoscopy is a very safe, reliable and effective procedure. There were no major surgical or anaesthetic complications in any of our patients except minimal abdominal pain and minimal per vaginal bleeding in some.

Uterine pathologies were the cause of infertility in about $15 \%$ of infertile couples and were diagnosed in about $50 \%$ of infertile women. ${ }^{7,8}$ In our study, the most common intrauterine pathology in both the groups was 
uterine septum accounting for about $13.7 \%$. Among all congenital uterine abnormalities, septate uterus is the most common cause associated with highest reproductive failure rate. The incidence of asymptomatic endometrial polyps in infertile women has been reported to range from $10 \%$ to $32 \% .^{9,10}$ Developmental uterine anomalies have long been associated with pregnancy loss and obstetric complications, but the ability to conceive is generally not affected. This can explained why the incidence of uterine anomalies in primary infertility group was almost similar to those in secondary infertility group in this study. Although a diagnosis of septate uterus per se is not an indication for septoplasty, the reproductive performance of women with an uncorrected septum is rather poor ( $80 \%$ pregnancy loss, $10 \%$ preterm delivery, $10 \%$ term delivery) with most losses occurring in the first trimester (approximately 65\%). Pregnancy outcomes dramatically improved after surgical correction $(80 \%$ term delivery, $5 \%$ preterm delivery, $15 \%$ pregnancy loss). ${ }^{11}$ Previously, surgical correction of septate uterus was requiring abdominal metroplasty, which was associated with increased morbidity and future pregnancy complications due to uterine scar. Nowadays, the modern operative hysteroscopic techniques have made it easy and short day care procedure with less morbidity and early recovery. Therefore, septal resection is recommended more frequently now.

The next most common hysteroscopic abnormalities in our study were myomas and polyps similar to another study. ${ }^{4,12}$ The evidence to suggest that uterine myomas decrease fertility is inferential and relatively weak; the bulk of it is derived from studies that had compared the prevalence of myomas in fertile and infertile women or the reproductive performance of women with otherwise unexplained infertility before and after myomectomy. ${ }^{11,13}$ Various mechanisms by which myomas might adversely affect fertility include cornual myomas that involve or compress the interstitial segment of the tube, dysfunctional uterine contractility interfering with ovum or sperm transport or embryo implantation, and poor regional blood flow resulting in focal endometrial attenuation or ulceration. ${ }^{14}$ A prospective study of 224 infertile women who underwent hysteroscopy observed a $50 \%$ pregnancy rate after polypectomy. ${ }^{15}$

HSG and laparoscopy are the two classical methods for evaluation of tubal pathology, complementary to each other. Although pelvic ultrasonography and HSG are good enough to exclude gross intrauterine pathology, subtle changes need be found and treated with hysteroscopy. Hysteroscopy is good at treatment of proximal obstruction of fallopian tube and laparoscopy is good at treatment of peritubal adhesions and hydrosalpinx. Hysteroscopy and laparoscopy are the two methods for evaluation and treatment of tubal pathology and are complementary to each other. ${ }^{16}$ Snowden et al reported that the false negative rate of hysterosalpingography (HSG) was $13 \%$ and the false positive rate was $16 \% .^{17}$
The gold standard technique for diagnosing tuboperitoneal disorders is laparoscopy, which is a better predictor of future spontaneous pregnancy in infertile couples with unexplained infertility. ${ }^{18}$ Jayakrishnan et al from India detected pelvic pathology in $26.8 \%$ cases of infertile patients by laparoscopic evaluation. ${ }^{19}$ In addition, endometriosis and adnexal adhesions were the two major abnormalities found among infertile patients in different studies similar to our findings. ${ }^{4,20,21}$ Adnexal adhesions and endometriosis $(41.6 \%)$ were the most common abnormalities detected in laparoscopy in primary and secondary infertility groups in our study. In contrast to a study by Godinjak et al we got equal prevalence of tubal block in both the groups of infertility patients, but this was almost similar to an another study by Nayak et al. ${ }^{4,20}$

Initially hysterolaparoscopy procedure may appear to be a costlier and invasive procedure, requiring anaesthesia but in the long run, it will become more beneficial as the therapeutic interventions can be done at the same sitting. Decisions for ART can be taken appropriately in time (if required).

\section{CONCLUSION}

Combined hystero-laparoscopy is a safe, effective and reliable method in comprehensive evaluation of infertility. Hystero-laparoscopy can also be called as the 'third eye' of gynaecologists in the evaluation of female infertility. Correctable structural abnormalities in pelvis may be unfortunately missed by routine pelvic examination and imaging procedures. It is a very useful tool in detecting these missed pelvic abnormalities in patients with the normal ovulation and husband semen analysis. It can be considered as a definitive day care procedure for evaluation of female infertility. It may be even recommended as the first and final procedure for evaluation of female infertility. It will also help us to take decision regarding the need for ART (Assisted Reproductive Technology) in required patients, thus avoiding further emotional and financial trauma to the couples. So, it helps in formulating an appropriate plan of management in infertility.

Funding: No funding sources Conflict of interest: None declared

Ethical approval: The study was approved by the Institutional Ethics Committee

\section{REFERENCES}

1. Mohr J, Lindemann HS. Hysteroscopy in the infertile patients. J. Reprod Med. 1977;19(3):161-2.

2. Rice JP, London SN, Olive DL. Re-evaluation of hysterosalpingography in infertility investigation. Obstet Gynaecol. 1986;67(5):718-21.

3. Yucebilgin MS, Aktan E, Bozkurt K, Kazandi M, Akercan F, Mgoyi L, et al. Comparison of hydrosonography and diagnostic hysteroscopy in the 
evaluation of infertile patients. Clin Exp Obstet Gynecol. 2004;31(1):56-8.

4. Nayak PK, Mahapatra PC, Mallick JJ, Swain S, Mitra S, Sahoo J. Role of diagnostic hysterolaparoscopy in the evaluation of infertility: A retrospective study of 300 patients. J Hum Reprod Sci. 2013;6(1):32-4.

5. Bettocchi S, Selvaggi L. A vaginoscopic approach to reduce the pain of office hysteroscopy. J Am Assoc Gynecol Laparosc. 1997;4:255-8.

6. Gour A, Zawiejska A, Mettler L. Hysteroscopy current trends and challenges. J Obstet Gynecol India. 2008;58(1):57-62.

7. Wallach EE. The uterine factor in infertility. Fertil Steril. 1972;23:138-58.

8. Brown SE, Coddington CC, Schnorr J, Toner JP, Gibbons W, Oehninger S. Evaluation of outpatient hysteroscopy, saline infusion hysterosonography, and hysterosalpingography in infertile women: A prospective, randomized study. Fertil Steril. 2000;74:1029-34.

9. Hinckley MD, Milki AA. 1000 office-based hysteroscopies prior to in vitro fertilization: Feasibility and findings. JSLS. 2004;8:103-7.

10. Shalev J, Meizner I, Bar-Hava I, Dicker D, Mashiach $\mathrm{R}$, Ben-Rafael Z. Predictive value of transvaginal sonography performed before routine diagnostic hysteroscopy for evaluation of infertility. Fertil Steril. 2000;73:412-7.

11. Donnez J, Jadoul P. What are the implications of myomas on fertility? A need for a debate? Hum Reprod. 2002;17:1424-30.

12. Kamiński $\mathrm{P}$, Wieczorek $\mathrm{K}$, Marianowski L. Usefulness of hysteroscopy in diagnosing sterility. Ginekol Pol. 1992;63:634-7.

13. Pritts EA. Fibroids and infertility: A systematic review of the evidence. Obstet Gynecol Surv. 2001;56:483-91.

14. Vollenhoven BJ, Lawrence AS, Healy DL. Uterine fibroids: A clinical review. $\mathrm{Br} \mathrm{J}$ Obstet Gynaecol.1990;97:285-98.
15. Shokeir TA, Shalan HM, EI-Shafei MM. Significance of endometrial polyps detected hysteroscopically in eumenorrheic infertile women. J Obstet Gynaecol Res. 2004;30:84-9.

16. Vaid K, Mehra S, Verma M, Jain S, et al. Pan endoscopic approach "hysterolaparoscopy" as an initial procedure in selected infertile women. J Clin Diagn Res. 2014;8(2):95-8.

17. Snowden EU, Jasset JC, Dawood MY. Comparison of diagnostic accuracy of laparoscopy, hysteroscopy and hysterosalpingography in evaluation of female infertility. Fertil Steril. 1984;41(5):709-13.

18. Mol BW, Collins JA, Burrows EA, van der Veen F, Bossuyt PM. Comparison of hysterosalpingography and laparoscopy in predicting fertility outcome. Hum Reprod. 1999;14:1237-42.

19. Jayakrishnan K, Koshy AK, Raju R. Role of laparohysteroscopy in women with normal pelvic imaging and failed ovulation stimulation with intrauterine insemination. J Hum Reprod Sci. 2010;3:20-4.

20. Godinjak Z, Idrizbegovic E. Should diagnostic hysteroscopy is a routine procedure during diagnostic laparoscopy in infertile women. Bosn J Basic Med Sci. 2008;8:44-7.

21. Tsuji I, Ami K, Miyazaki A, Hujinami N, Hoshiai H. Benefit of diagnostic laparoscopy for patients with unexplained infertility and normal hysterosalpingography findings. Tohoku J Exp Med. 2009;219:39-42.

Cite this article as: Ramesh B, Kurkuri SN. The role of combined hystero-laparoscopy in the evaluation of female infertility as one step procedure: a retrospective analytical study of 250 patients. Int J Reprod Contracept Obstet Gynecol 2016;5:396-401. 